\title{
Deteksi Wajah Secara Real Time Menggunakan Metode Camshift
}

\author{
Rita Susanti, Nurul Fadillah \\ Program Studi Teknik Informatika, Fakultas Teknik, Universitas Samudra \\ Email : ${ }^{1}$ susantirita490@gmail.com, ${ }^{2}$ nurulfadillah@unsam.ac.id
}

\begin{abstract}
Abstrak
Penelitian pengenalan wajah, saat ini sudah menjadi topik penelitian yang ditekuni oleh banyak peneliti baik dalam negeri maupun luar negeri karena banyak manfaat dan guna dari hasil penelitian. Beberapa manfaat dari penelitian pengenalan wajah antara lain untuk system keamanan dan robotika. Peneliti pengenalan wajah sudah mulai berkembang beberapa dekade terakhir dan sudah banyak diaplikasikan terutama untuk sistem keamanan. Banyak metode yang bisa digunakan dalam pengenalan wajah, salah satunya adalah pengenalan wajah secara real time dengan menggunakan metode Camshift, Berdasarkan hasil uji coba terhadap pose wajah yang berbeda-beda dimana tiap-tiap posisi citra wajah diambil samplenya sebagai data pelatihan dengan berbagai posisi pose dan memiliki hasil yang berbeda, Dalam percobaan ini, terdiri dari beberapa pengujian yaitu pengujian terhadap deteksi dan penjajakan wajah serta pengujian pengenalan wajah dilakukan dalam empat jenis pengujian yaitu pengujian pengenalan wajah pada jarak $30 \mathrm{~cm}$, pengujian pengenalan wajah pada jarak 50 $\mathrm{cm}$, pengujian pada jarak $100 \mathrm{~cm}$ dan pengujian menggunakan aksesories.
\end{abstract}

Kata Kunci: citra, deteksi wajah, metode camshift, real time

\begin{abstract}
Face recognition research has now become a research topic that is occupied by many researchers both domestically and abroad because of the many benefits and uses of the research results. Some of the benefits of research introduce faces include security systems and robotics. Researchers introduced faces that have begun to develop the last few and have been applied mainly to security systems. Many methods can be used in face recognition, one of which is face recognition in real time using the Camshift method, Based on the results of trials on poses Having different results, In this experiment, it consisted of several tests namely testing of face detection and assessment and testing face is carried out in four types of testing, namely face recognition testing at a distance of $30 \mathrm{~cm}$, face recognition testing at a distance of $50 \mathrm{~cm}$, testing at a distance of $100 \mathrm{~cm}$ and testing using accessories.
\end{abstract}

Keywords: image, face detection, camshift method, real time

\section{PENDAhuluan}

Penelitian pengenalan wajah sudah mulai berkembang dengan pesat dalam beberapa dekade terakhir baik pengenalan wajah dengan menggunakan citra diam (scane foto) ataupun dengan menggunakan vidio(real time). Biometriks secara teoritis dapat lebih efektif untuk mengindentifikasi pribadi seseorang karena biomatriks mengukur karakteristik masing-masing pribadi untuk membedakan setiap orang. Tidak seperti dengan metoda indentifikasi konvensional, misalnya kartu indentitas, seperti password untuk login ke system komputer dan lainlain. Ketika digunakan untuk indentifikasi pribadi, teknologi biometriks mengukur dan menganalisa karakteristik tingkah laku dan fisiologis manusia. Mengindentifikasi karakteristik fisiologis seseorang yang didasarkan pada pengukuran langsung bagian dari body-fingertips, hand geometry, facial geometry, eye retinas serta irises dan face recognation.

Citra bergerak (video) Penelitian tentang pengenalan wajah manusia merupakan salah satu bidang ilmu yang berkembang saat ini, pemanfaatan aplikasi pengenalan wajah dapat digunakan pada bidang keamanan (security system) seperti pengawasan lokasi (surveillance), ijin akses masuk ruangan, dan kamus digital, absensi serta sistem cerdas. Pengenalan wajah merupakan identifikasi personal yang didasarkan dari geometrik atau fitur statistik yang di dapat dari citra wajah manusia. Dalam proses pengenalan wajah dipengaruhi oleh beberapa faktor variabilitas, yaitu variabilitas extra-personal faktor ini timbul karena proses pengenalan wajah dilakukan pada wajah yang berbeda karena faktor ras dan genetika, sedang variabilitas intra-personal adalah variasi yang muncul pada wajah yang sama dimana hal ini disebabkan oleh perubahan-perubahan internal (deformations) seperti posisi wajah, keberadaan komponen struktural, ekspresi wajah, oklusi, orientasi citra,dan kondisi pencitraan.

\subsection{Tahapan Penelitian}

\section{TEORITIS}

Pembuatan sistem akan dirancang secara real time dengan metode camshift. Pembahasan akan dimulai dari perancangan sistem menggunakan diagram alir hingga metode yang digunakan dalam pembuatan sistem. Pengambilan data citra wajah diambil dengan menggunkan youcame yang terdapat pada laptop. Objek yang diambil merupakan wajah manusia. Berikut merupakan alur tahapan perancangna sistem. 


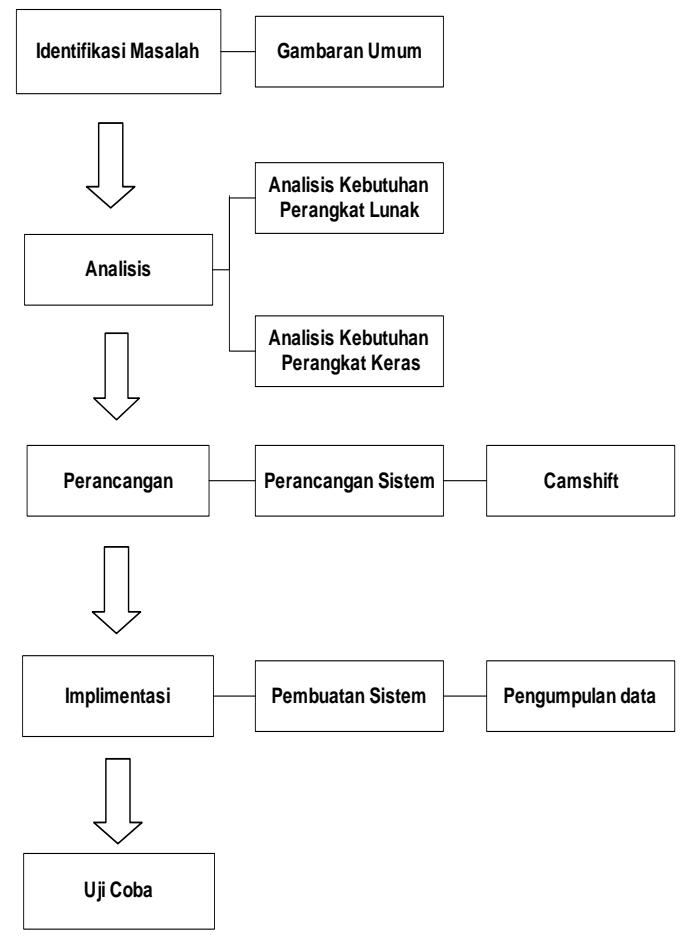

Gambar 1. Bagan Tahap Perancangan Sistem

Pada Gambar 2.1 tahap pertama dari pembuatan sistem adalah identifikasi masalah yang akan membahas mengenai masalah pengenalan wajah yang bisa digunkan sebagai identitas pengenalan yang bsa mengenali nama pemilik wajah. Kemudian dilanjutkan dengan menganalisis masalah tersebut sehingga bisa ditemukan sebuah solusi untuk memecahkan masalah. Analisis yang dilakukan akan membahas mengenai analisis kebutuhan perangkat lunak dan analisis kebutuhan perangkat keras. Solusi dari masalah akan dirancang menjadi sebuah bentuk aplikasi dengan menggunakan diagram alir agar alur aplikasi bisa dijabarkan dengan jelas. Ujicoba merupakan tahapan metode penelitian yang diperlukan untuk menilai apakah hasil dari penelitian ini sesuai dengan tujuan dan dapat memenuhi ekspektasi pembuat aplikasi dan pengguna, ujicoba akan dilakukan dengan menjalankan sistem dan melihat seberapa besar tingkat keberhasilan pengenalan wajah yang sedang dideteksi menggunakan youcame laptop.

\subsection{Deteksi Wajah}

Pendeteksian wajah (face detection) juga merupakan salah satu tahap awal yang sangat penting sebelum dilakukan proses pengenalan wajah (face recognition). Deteksi wajah dapat dipandang sebagai masalah klasifikasi pola dimana inputnya adalah suatu citra dan outputnya adalah label kelas dari citra tersebut. Dalam hal ini terdapat dua label kelas, yaitu wajah dan non-wajah .

Secara dasar ada empat pendekatan berbeda dalam permasalahan deteksi wajah , yaitu:

1. Metode berbasis pengetahuan: Aturan didapatkan berdasarkan pengetahuan manusia mengenai fitur terdefinisi dari wajah sesorang manusia. Mayoritas dari aturan-aturan ini membahas tentang hubungan antar fitur.

2. Metode invarian fitur: algoritma dirancang untuk mencari fitur struktural dari wajah yang invariant terhadap masalah umum mengenai pose, halangan, ekspresi, kondisi citra, dan pengrotasian.

3. Metode pencocokan template: dengan suatu set sampleyang diberikan, sebuah set pola wajah standar yang serupa dapat dihasilkan. Hubungan antara citra sample dan set pola yang telah didefinisikan dapat dihitung dan digunakan untuk menarik kesimpulan.

4. Metode berbasis penampilan: mirip dengan metode pencocokan template. Tujuannya adalah untuk mendapatkan keakuratan yang lebih tinggi dengan variasi yang lebih besar pada data latih

\subsection{Citra}

Citra adalah suatu representasi (gambaran), kemiripan, atau imitasi dari suatu obyek. Citra sebagai keluaran suatu sistem perekaman data dapat bersifat optik berupa foto, bersifat analog berupa sinyal-sinyal video seperti gambar pada monitor televisi, atau bersifat digital yang dapat langsung disimpan pada suatu media penyimpan, Sedangkan citra digital pada umumnya berbentuk empat persegi panjang dengan dimensi ukurannya dinyatakan 
sebagai lebar x tinggi y. Citra digital memiliki koordinat spasial, dengan tingkat kecerahan atau intensitas cahaya (skala keabu-abuan) yang memiliki numeric yang diskrit dipresentasikan dalam bentuk fungsi matematis $\mathrm{f}(\mathrm{x}, \mathrm{y})$ yang menyatakan intensitas cahaya pada titik $(\mathrm{x}, \mathrm{y})$ itu sendiri[2].

\subsection{Preprocessing}

Preprocessing adalah tahap sebelum tahap inti yang bertujuan untuk mempermudah analisis berikutnya, dalam penelitian ini beberapa preprocessing yang dilakukan adalah grayscale dan resize.

\subsection{Camshift}

Deteksi dan penjajakan (tracking) wajah dalam penelitian ini menggunakan metode Camshift yang merupakan singkatan dari Continously Adaptive Mean Shift dan hasil pengembangan dari algoritma Mean Shift yang dilakukan secara terus menerus untuk melakukan adaptasi atau penyesuaian terhadap distribusi probabilitas warna yang selalu berubah tiap pergantian frame dari video

langkah-langkah kerja metode Camshift adalah sebagai berikut:

1. Tentukan ukuran awal search window

2. Tentukan lokasi awal dari search window

3. Tentukan daerah kalkulasi (calculation region) pada bagian tengah search window dengan ukuran lebih besar dari search window

4. Frame citra video dikonversi ke dalam sistem warna HSV (hue, saturation,value)

5. Lakukan algoritma mean shift seperti diatas (satu atau banyak iterasi) dengan input berupa ukuran dan lokasi search window serta citra distribusi probabilitas warna dan simpan zeroth moment

6. Set nilai $\mathrm{x}, \mathrm{y}, \mathrm{z}$ yang diperoleh dari langkah 5

7. Nilai $x$ dan y dipakai untuk menentukan titik tengah search window, sedangkan $(2 \mathrm{X}$ area $1 / 2)$ untuk menentukan ukuran search window

8. Ulangi langkah 3 untuk setiap pergantian frame citra video.

\section{Perancangan Sistem}

Cara kerja sistem pengenalan wajah secara real time yang dibangun, secara umum ditunjukkan pada diagram alir berikut ini :

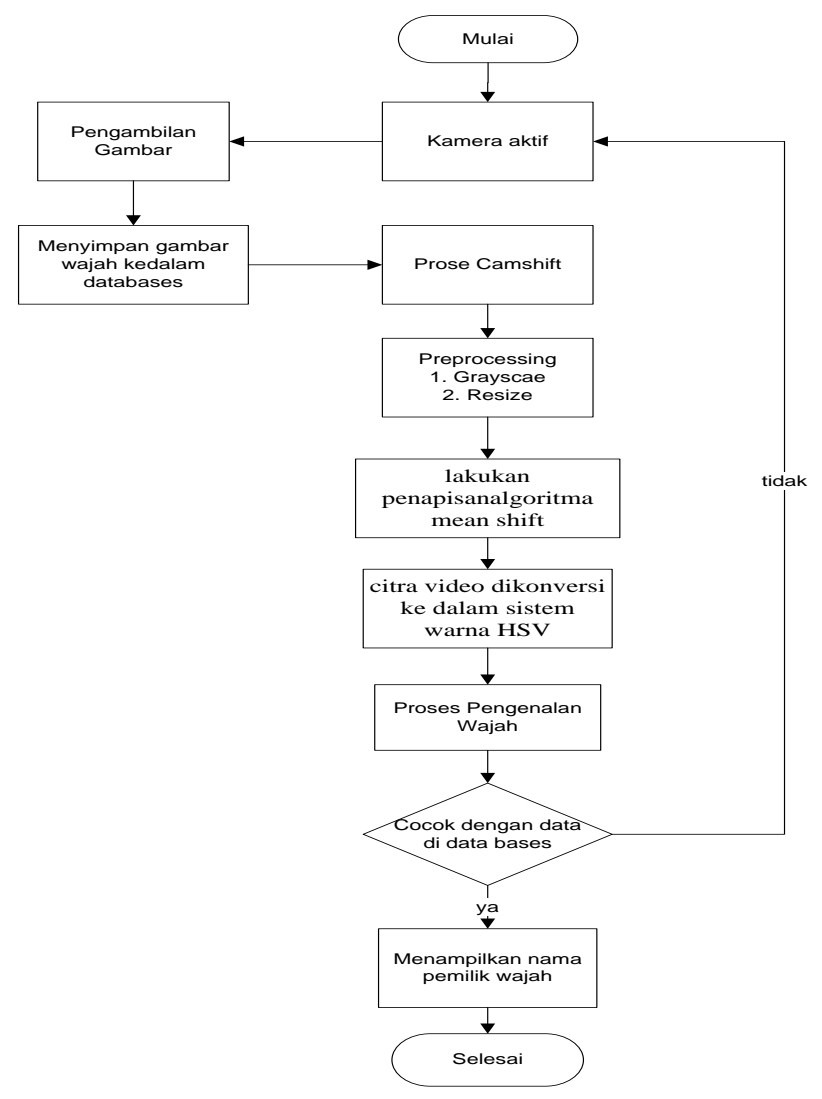

Gambar 2. Flowchart Perancangan Sistem

Pada gambar 2.2 flowchart diatas, setelah sistem dimulai maka kamera akan aktif kemudian dilakukan pengambilan gambar wajah dan memberikan pengenalan nama pada saat proses penyimpanan kedalam data 
bases, untuk pengenlan selanjutnya akan dilakukan menggunakan metode camshift dan gambar akan diubah menjadi grayscale dan mengubah resolusi atau ukuran horizontal dan vertikal pada ctra yang ditangkap, setelah itu akan dilakukan penepisan menggunakan algoritma mean shift, citra vidio yang dilakukan secara real time akan dikonversi kedalam bentuk HSV dan wajah akan diidentifikasi, jika wajah coco dengan data di dalam databases yang sudah diinput sebelumnya maka sistem akan mengenai nama pemilik wajah yang sedang diidentifikasi, jika data tidak cocok maka sistem akan kembali pada kamera on untuk melakukan proses pengambilan gambar wajah terlebih dahulu.

\section{ANALISA DAN PEMBAHASAN}

Dalam percobaan ini, terdiri dari beberapa pengujian yaitu pengujian terhadap deteksi dan penjajakan wajah serta pengujian pengenalan wajah dilakukan dalam empat jenis pengujian yaitu pengujian pengenalan wajah pada jarak $30 \mathrm{~cm}$, pengujian pengenalan wajah pada jarak $50 \mathrm{~cm}$, pengujian pada jarak $100 \mathrm{~cm}$ dan pengujian menggunakan aksesories.

\subsection{Pengujian Camshift}

Hasil deteksi dan penjajakan sebagaimana ditunjukan oleh gambar 3 yang merupakan hasil deteksi berdasarkan warna yang menyerupai warna kulit manusia yang dituangkan ke dalam algoritma camshift. Kemudian yang dibatasi oleh garis kuning adalah hasil pengukuran menggunakan boundary box. Hasil dari deteksi wajah ini adalah sebagai dasar untuk melakukan penjajakan (tracking) wajah, dalam melakukan tracking wajah algoritma Camshift didasarkan pada warna kulit wajah, karena warna kulit wajah menyediakan banyak kontras antara wajah dan latar belakang.

a. Berikut gambar hasil deteksi dan tracking wajah, dengan jarak posisi wajah dengan kamera $30 \mathrm{~cm}$

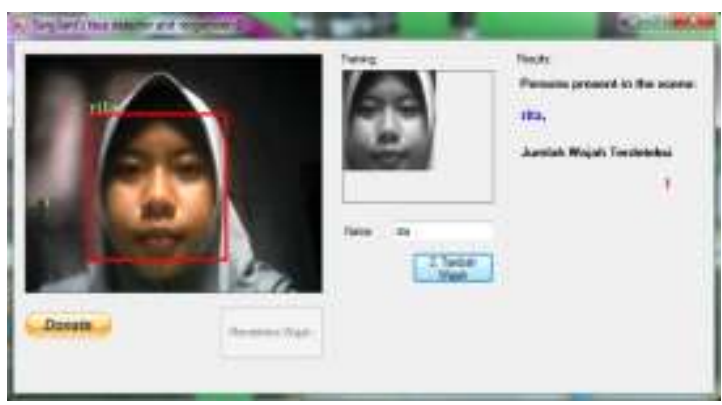

Gambar 3. Deteksi Wajah Dalam Keadaan Lurus Menghadap Kamera

Dari hasil percobaan dapat dilihat bahwa wajah dapat terdeteksi jika menghadap lurus pada arah kamera, seperti pada percobaan diatas bahwa wajah dapat dikenali dengan pemilik nama yaitu "rita" selain itu jumlah wajah yang terdeteksi juga dapat terdeteksi yaitu satu wajah yang terdeteksi.

b. hasil deteksi dan tracking wajah dengan jarak posisi wajah dengan kamera $50 \mathrm{~cm}$

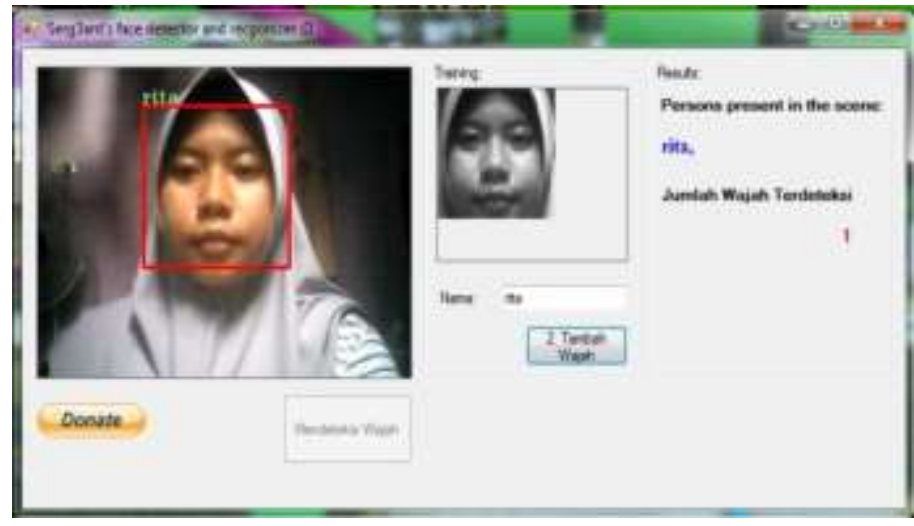

Gambar 4. Deteksi Wajah Dalam Keadaan Lurus Menghadap Kamera

Dari hasil percobaan dapat kita lihat pada jarak $50 \mathrm{~cm}$ antara wajah dengan camera masih dapat terdeteksi dan masih dapat dikenali, dengan pemilik nama "rita" dan jumlah wajah yang terdeteksi juga masih dapat terbaca yaitu camera menangkap 1 wajah yang terdeksi

c. hasil deteksi dan tracking wajah dengan jarak posisi wajah dengan kamera $100 \mathrm{~cm}$ 


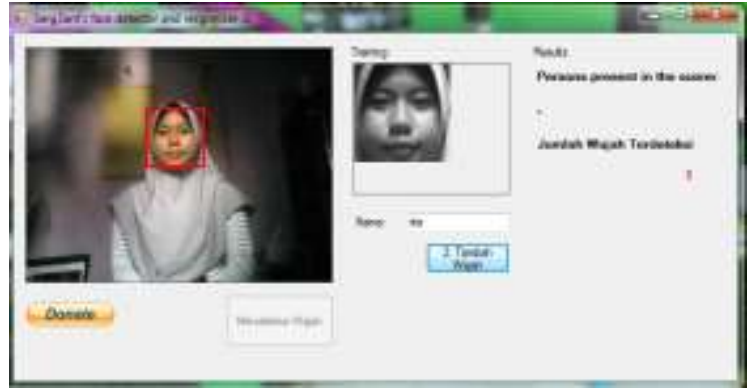

Gambar 5.Deteksi Wajah Dalam Keadaan Lurus Menghadap Kamera

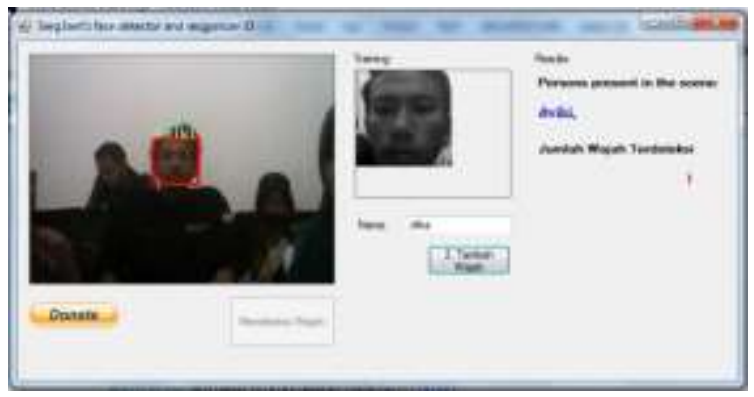

Gambar 6. Deteksi Wajah Dalam Keadaan Lurus Menghadap Kamera

Dari hasil percobaan dapat kita lihat pada jarak $100 \mathrm{~cm}$ antara wajah dengan camera masih dapat terdeteksi namun wajah tidak dapat dikenali dalam waktu dekat, tetapi masih dapat dikenalin dengan waktu yang sedikit lama, jumlah wajah yang terdeteksi juga masih dapat terbaca yaitu camera menangkap 1 wajah yang terdeksi.

d. Percobaan deteksi wajah menggunakan aksesories(keadaan tertutup)

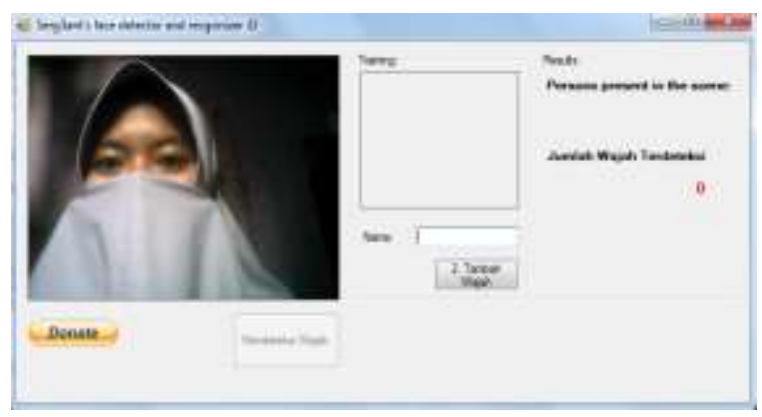

Gambar 7. Deteksi Wajah Dalam Keadaan Tertutup

Dari hasil percobaan dapat dilihat bahwa pengujian deteksi wajah dalam keadaan bagian wajah tertutup maka program tidak dapat mendeteksi apalagi mengenali wajah, jumlah wajah pada percobaan wajah tertutup juga tidak dapat terbaca

e. hasil deteksi dan tracking wajah dengan keadaan wajah miring

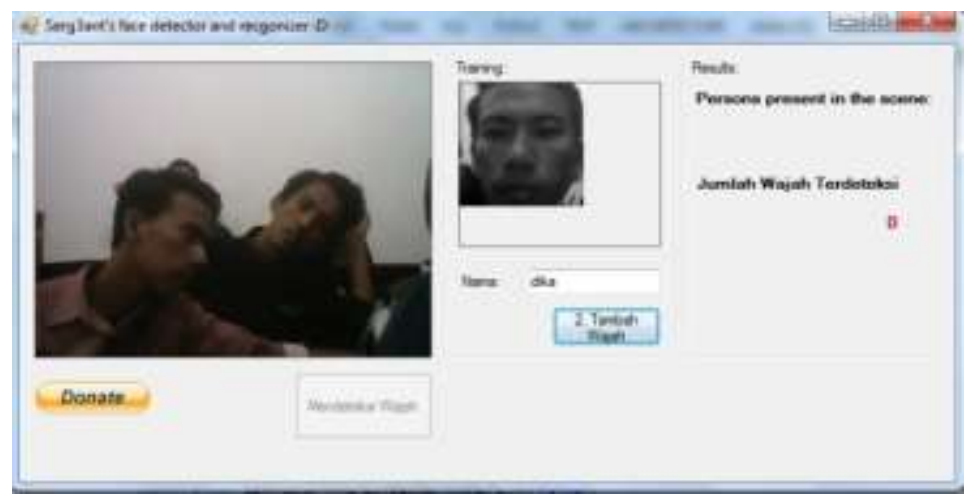

Gambar 8. Deteksi Wajah Dalam Keadaan Waja Miring 
Dari hasil percobaan dapat dilihat bahwa pengujian deteksi wajah dalam keadaan bagian wajah miring tidak dapat terdeteksi dan mengenali wajah, jumlah wajah pada percobaan wajah miring juga tidak dapat terbaca.

\subsection{Pengujian pengenalan citra wajah}

\section{IMPLEMENTASI}

Pengujian yang dilakukan dalam penelitian ada beberapa ketentuan yaitu citra wajah adalah citra wajah orang Indonesia yang memiliki pose berbeda pada setiap percobaan untuk mendeteksi wajah, hasilnya kemudian dibandingkan dengan masing-masing frame dari data yang telah diambil. Berdasarkan hasil uji coba maka dapat dilakukan analisa bahwa semakin jauh jarak antara kamera dengan obyek maka semakin kecil hasil akurasi pengenalannya, ini dikarenakan semakin jauh obyek dengan titik fokus kamera semakin kecil pixel dari citra sehingga apabila dilakukan resizing menjadi 200 x 200 pixel, maka citra akan menjadi blur atau pecah yang akibatnya akan berpengaruh terhadap penurunan hasil pengenalan.

Selain memiliki tingkat pengenalan yang baik, penelitian pengenalan wajah secara real time juga memiliki beberapa kelemahan diantaranya adalah sensitif terhadap noise. Dimana dari hasil pengujian, apabila pencahayaan kurang stabil misalnya terlalu terang ataupun terlalu gelap, maka akan berpengaruh terhadap tingkat pengenalan, begitu juga pergerakan obyek, apabila pergerakan obyek terlalu cepat, maka tidak akan dikenali, sehingga dalam penelitian ini obyek bergerak secara lambat atau slow motion . Kemudian yang berikutnya adalah dari jenis kamera atau webcam, apabila kamera atau webcam "ganta-ganti" maka akan berpengaruh terhadap tingkat pengenalan begitu juga terhadap waktu komputasi, karena setiap kamera / webcam memilliki kecepatan yang berbeda - beda. Berikut merupakan tabel hasil percobaan.

Tabel 1. Hasil Percobaan

\begin{tabular}{|c|c|c|c|c|}
\hline \multirow{3}{*}{ No } & \multirow{3}{*}{ Posisi Wajah } & & \multicolumn{2}{|c|}{ Wajah teridentifikasi } \\
\hline & & Jarak Wajah & & \\
\hline & & Dengan youcame & ya & tidak \\
\hline \multirow[t]{2}{*}{1.} & Lurus menghadap kamera & & & - \\
\hline & & $30 \mathrm{~cm}$ & yа & \\
\hline \multirow[t]{2}{*}{2.} & Lurus menghadap kamera & & & - \\
\hline & & $50 \mathrm{~cm}$ & уа & \\
\hline \multirow[t]{2}{*}{3.} & Lurus menghadap kamera & & Membutuhkan & - \\
\hline & & $100 \mathrm{~cm}$ & yang lama & \\
\hline \multirow[t]{2}{*}{4.} & wajah dalam keadaan & & & \\
\hline & tertutup & Dekat-jauh & - & tidak \\
\hline \multirow[t]{2}{*}{5.} & dalam keadaan & & & \\
\hline & miring & Dekat -jauh & - & tidak \\
\hline
\end{tabular}

\subsection{Tampilan Menu Pada Program}

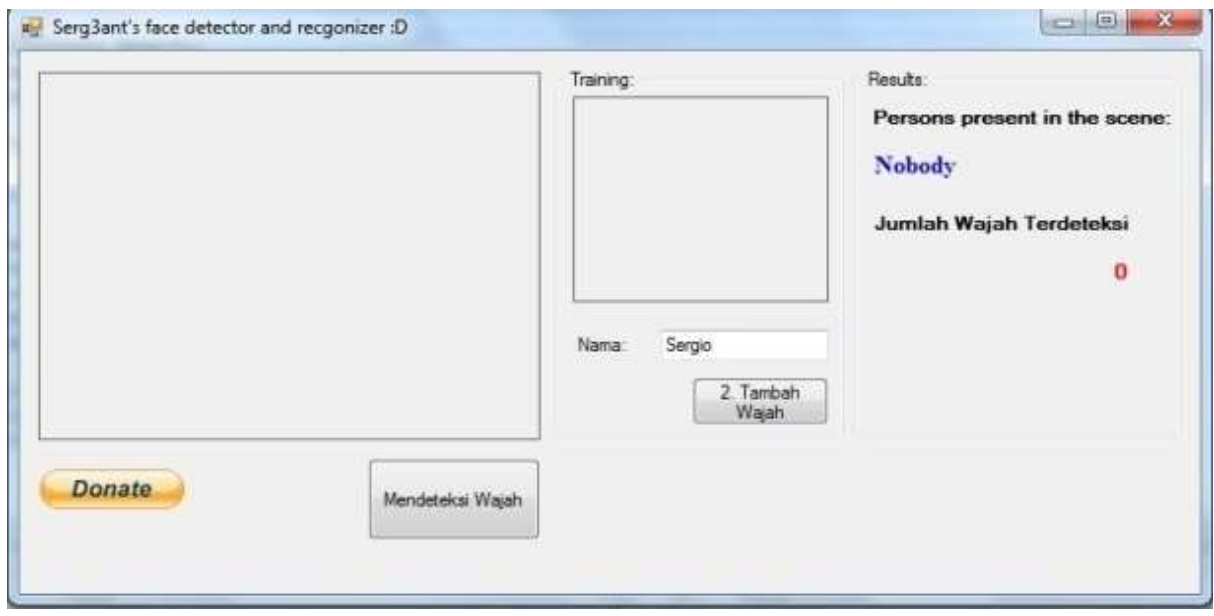

Gambar 9. Tampilan Awal pada program 


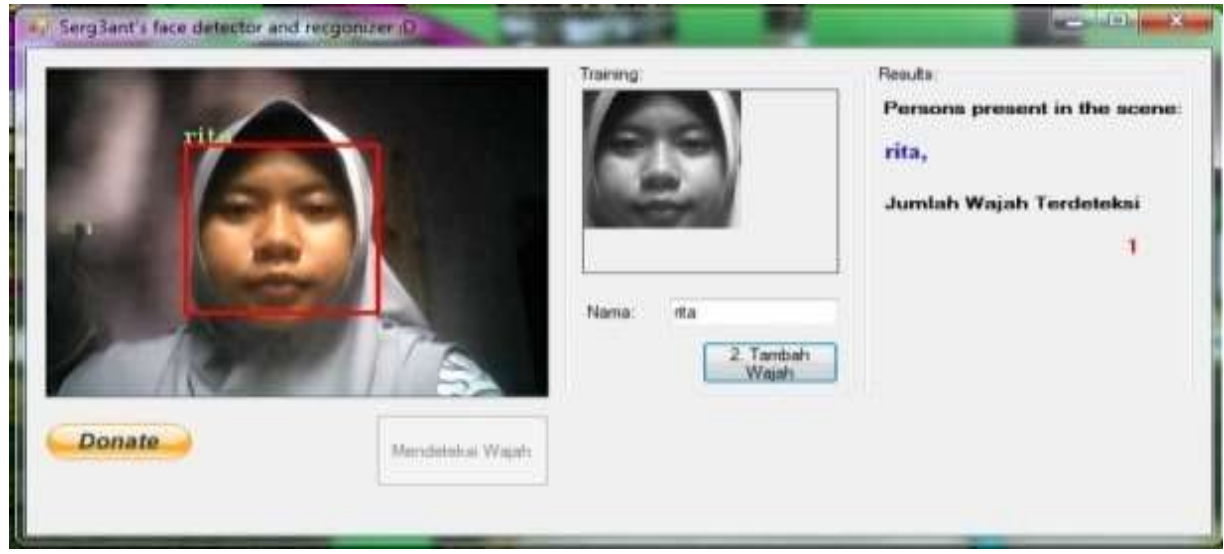

Gambar 10. Tampilan pengenalan wajah pada program

\section{KESIMPULAAN}

Dari hasil percobaan sistem yang telah dilakukan pada dapat ditarik bebrapa kesimpuan

1. Dalam melakukan pengenalan wajah terdiri dari beberapa tahapan yaitu preprocessing, filtering, ektraksi baru kemudian dilakukan pencocokan atau pengenalan citra wajah.

2. Dari segi waktu komputasi dalam mendeteksi dan mengenali wajah memiliki akurasi pengenalan dengan waktu komputasi yang tetap stabil.

3. Metode yang digunakan ini masih ada beberapa titik lemah yaitu metode camshaft akan mendeteksi dan mentracking objek yang memiliki warna apabila objek tersebut mirip atau sama dengan warna citra wajah walaupun itu bukan wajah manusia dan apabila ada kumpulan titik atau pixel yang memiliki warna mirip wajah juga akan dianggap wajah

4. Dan dari hasil percobaan bahwa semakin jauh jarak antara kamera dengan obyek maka semakin kecil hasil akurasi pengenalannya, ini dikarenakan semakin jauh obyek dengan titik fokus kamera semakin kecil pixel dari citra sehingga apabila dilakukan resizing menjadi 200 × 200 pixel, maka citra akan menjadi blur atau pecah yang akibatnya akan berpengaruh terhadap penurunan hasil pengenalan.

\section{REFERENCES}

[1] Aparna Behara et al, Real Time Face Recognition System For Time And Attendance Applications, Department of E and CE, NIT Warangal, INDIA 506004, IEEE. 2013

[2] Bobby Yuliandra et al, People Counting using Extended CAMSHIFT and Haar-like Features, Fakultas Informatika, Telkom University. 2016

[3] Derisma, Faktor-Faktor yang Mempengaruhi Sistem Pengenalan Wajah Menggunakan Metode Eigenface pada Perangkat Mobile Berbasis Android, Vol.2, No. 2, November 2016, 127-136

[4] Klaus Kollreider, Real-time Face Detection and Motion Analysis with Application in "Liveness" Assessment, IEEE. 2017

[5] Kardas P.A.T.R et al, Rancang Bangun Aplikasi Augmented Reality Sebagai Media Promosi Model Tatanan Rambut Pada Barbershop Berbasis Android. Vol. 1 No 1 - April 2018 p-ISSN 2598-7305 (Print), e-ISSN 2598-9642 (Online)

[6] N.Niranjani et al, The Real Time Face Detection and Recognition System, Information and Communication Technology Center, University College of Jaffna, University of Vocational Technology, Sri Lanka. 2017

[7] Ramadha Gilang et al, Klasifikasi Identitas Wajah Untuk Otorisasi Menggunakan Deteksi Tepi dan LVQ. 2016

[8] Sultoni et al, Pengenalan Wajah Secara Real Time Menggunan Metode Camshift, Lapalcian of Gaussian Dan Discrete Cosine Transformtwo Dimensional (LoGDCT2D), Fakultas Teknik, Universitas Brawijaya,2016

[9] Sumolong B.B et al, Aplikasi Absensi Jemaat Berbasis Android, Vol 13, No 2 (2018) ISSN: 2301-8364 